\title{
Minireviews
}

\section{MicroRNA-Directed Cancer Therapies: Implications in Melanoma Intervention}

\author{
Anita Thyagarajan, ${ }^{1}$ Ahmed Shaban, ${ }^{1}$ and Ravi Prakash Sahu ${ }^{1}$ \\ Department of Pharmacology and Toxicology, Boonshoft School of Medicine, Wright State University, Dayton, Ohio (A.T., \\ R.P.S.); and Department of Pharmacology, Faculty of Veterinary Medicine, Zagazig University, Zagazig, Egypt (A.S.)
}

Received May 12, 2017; accepted August 22, 2017

\section{ABSTRACT}

Acquired tumor resistance to cancer therapies poses major challenges in the treatment of cancers including melanoma. Among several signaling pathways or factors that affect neocarcinogenesis, cancer progression, and therapies, altered microRNAs (miRNAs) expression has been identified as a crucial player in modulating the key pathways governing these events. While studies in the miRNA field have grown exponentially in the last decade, much remains to be discovered, particularly with respect to their roles in cancer therapies. Since immune and nonimmune signaling cascades prevail in cancers, identification and evaluation of miRNAs, their molecular mechanisms and cellular targets involved in the underlying development of cancers, and acquired therapeutic resistance would help in devising new strategies for the prognosis, treatment, and an early detection of recurrence. Importantly, in-depth validation of miRNA-targeted molecular events could lead to the development of accurate progression-risk biomarkers, improved effectiveness, and improved patient responses to standard therapies. The current review focuses on the roles of miRNAs with recent updates on regulated cell cycle and proliferation, immune responses, oncogenic/epigenetic signaling pathways, invasion, metastasis, and apoptosis, with broader attention paid to melanomagenesis and melanoma therapies.

\section{Introduction}

MicroRNAs (miRNAs) are a class of evolutionally conserved single-stranded noncoding RNAs of 19-22 nucleotides (Bartel, 2004). miRNAs are encoded within the genome from intronic, exonic, or intergenic regions and are initially part of immature primary transcripts (primary miRNAs) that can be of several kilobases in length. The biogenesis of miRNA involves the cleavage of primary miRNAs by the RNAse enzyme, Drosha, followed by its transcription to 60-100 nucleotide hairpin precursor RNAs (precursor miRNA). The precursor miRNA is then transported to the cytoplasm by the nuclear export factor exportin-5 and is excised by the RNA polymerase enzyme Dicer to produce 70-nucleotide-long precursor miRNAs. Finally, putative helicase unwind these precursor miRNAs to mature 18-24 nucleotides miRNAs (Pillai et al., 2004). Single-stranded mature miRNAs associate with argonaute proteins to form the core of a multicomponent gene regulatory complex known as the RNA-induced silencing complex

This work was supported by grants from the National Institutes of Health National Institute of Environmental Health Sciences K22 [Grant ES023850] and Wright State University [Grant 190002].

The authors declare no competing conflicts of interest.

${ }^{1}$ A.T., A.S., and R.P.S. contributed equally to this work.

https://doi.org/10.1124/jpet.117.242636.
(Bartel, 2004). This RNA-induced silencing complex facilitates miRNA-mediated regulation of gene expression through base pairing between miRNA and sequence(s) within the $3^{\prime}$ untranslated region of the target messenger RNA [mRNA, i.e., between the protein-coding region of mRNA and its poly(A) tail] (Pillai et al., 2004). The binding of miRNA to mRNA reduces translation rate and/or increases degradation of mRNA (Vasudevan et al., 2007). However, recent evidence suggests that miRNAs may also increase mRNA translation when cells are undergoing cell cycle arrest (Vasudevan et al., 2007). In general, miRNA half-life ranges from hours to days and varies depending on the organs, body fluids, and cell types (van Rooij et al., 2007). In comparison with mRNA, miRNAs are highly stable in formalin-fixed paraffin-embedded tissue blocks or biobank stored animal and human biosamples, which allow its use for localization and expression studies as biomarkers even after years of storage (Hall et al., 2012; Samir and Pessler, 2016).

miRNAs play important roles in essentially all biologic processes (Tufekci et al., 2014). The differential expression of host miRNAs during infection has supported the idea that they may constitute key players in host responses to invading pathogens (Lee et al., 1993; Ambros, 2004). It has been recognized that the regulatory roles of miRNAs are much more sophisticated than initially thought due to the cooperativity 
(i.e., more than one miRNA species can target the same mRNA) and the multiplicity of their targets (i.e., one miRNA can target hundreds of mRNA species) (Scaria et al., 2006). Three basic mechanisms of miRNA-mediated gene regulation are present: translation repression, direct mRNA degradation, and miRNAmediated mRNA decay (Guo et al., 2010). Importantly, recent data suggest that the repression mechanism is predominately governed by reduction in mRNA target stability (Guo et al., 2010). Notably, miRNAs have been implicated in mediating a broad range of processes including cell cycle and differentiation; regulation of metabolic pathways involved in lipid metabolism, inflammation, and neurologic, cardiovascular, and metabolic disorders; apoptosis; cancer development; and metastasis (Friedman et al., 2009; Lynn, 2009; Lages et al., 2012; Lorenzen et al., 2012; O'Connell et al., 2012; Salta and De Strooper, 2012).

Discovery of miRNA. In the early 1990s, during studies investigating the timing of embryonic development of different larval stages of the worm, Caenorhabditis elegans, Lee et al. (1993) observed that the RNA transcribed from the lin-4 locus did not encode a protein but instead silenced the gene encoding Lin-14, an important protein in larval development. The lin-4 containing complementary sequences in the $3^{\prime}$ untranslated region of lin-14 mRNA illustrated a regulatory mechanism by which lin-4 could modulate lin-14 mRNA translation in C. elegans, leading to temporal pattern formation during development (Lee et al., 1993; Wightman et al., 1993). Additionally, the discovery that miRNAs are involved in sensing nutrient stress in plants, or mediating responses to environmental stress as one of the mechanisms deployed to reprogram the gene expression such that cells can adapt to changing environments, has opened new horizons in relation to identifying their functions in human diseases (Chiou, 2007; Holtz and Pasquinelli, 2009; Leung and Sharp, 2010; Mendell and Olson, 2012).

The biogenesis and modes of miRNA mechanisms have not been completely elucidated. However, miRNA-mediated translational repression has been reported to be involved in regulating almost every cellular process. The regulatory patterns of several other miRNAs have now been identified in species ranging from viruses to humans (Berezikov et al., 2006). The latest version of miRBase (miRBase version 16.0 Griffiths-Jones lab at the Faculty of Life Sciences, University of Manchester, United Kingdom.) has 1048 miRNA sequences annotated in the human genome, and additional miRNAs will likely be validated in the future (Berezikov et al., 2005; Griffiths-Jones et al., 2008; Shao et al., 2010; Persson et al., 2011). The literature indicates that one-third of these miRNAs are located in 113 gene clusters, and based on the evidence from miRNA profiling data in various tissues and cell lines these clusters are mostly coexpressed. This observation led to questions about cistronic expression regulatory patterns in gene clusters (Berezikov et al., 2005; Griffiths-Jones et al., 2008; Shao et al., 2010; Persson et al., 2011). The current understanding is that deregulation of one member of the cluster is accompanied by similar deregulations of other miRNAs from the same cluster. Thus, it would be crucial to ascertain whether one miRNA in a cluster can be regulated independently of others, especially in relation to those miRNAs that are implicated in the pathophysiology of human diseases (Karius et al., 2012). Of several protein-coding genes, miRNAs are believed to target approximately one-third of human
mRNAs, and due to differential target binding patterns a single miRNA may target approximately 200 transcripts simultaneously (Brennecke et al., 2005). Hence, an in-depth analysis of miRNA regulation might provide effective strategies to control numerous genes simultaneously (see Fig. 1).

\section{miRNAs in the Regulation of Cancer}

In particular, miRNAs are often aberrantly expressed in several human cancers including melanoma (with numerous miRNAs being overexpressed in one type of cancer and downregulated in another) (Nelson et al., 2006; Nelson and Weiss, 2008; Cortez et al., 2011; Bonazzi et al., 2012). For example, miR-205 is upregulated in lung, bladder, and pancreatic cancers (Nelson and Weiss, 2008; Cortez et al., 2011; Bonazzi et al., 2012). In contrast, miR-205 is significantly downregulated in prostate and esophageal squamous cell carcinomas, indicating that cancer-associated miRNAs cannot be generalized (Melo and Esteller, 2011). Nonetheless, cancer-specific miRNA expression signatures may prove useful as diagnostic and therapeutic tools. Interestingly, miRNA expression signatures have been linked to several clinicopathological variables such as tumor stage and metastasis, receptor status, disease recurrence, treatment resistance, and patient survival (Andorfer et al., 2011; Jiang et al., 2012). According to the personalized medicine model, miRNAassociated molecular taxonomy could help to predict the likelihood of patients developing resistance against a particular treatment. For example, studies in breast cancer patients revealed that both miR-451 and miR-27 were involved in developing resistance to doxorubicin (Andorfer et al., 2011). Additionally, overexpression of miR-125b was shown to induce resistance of breast cancer cells to paclitaxel (Zhou et al., 2010). Therefore, the analysis of miRNAs that affect drug sensitivity represents a potentially important area of investigation in understanding mechanistic insights contributing to drug resistance and clinical management of cancers.

\section{miRNAs and Regulation of Melanomagenesis and Progression}

Melanocytes are skin cells that originate from neural crest cells and have the ability to produce melanin pigment. Melanocyte differentiation occurs via a series of steps, resulting in lineage specification of melanoblasts and transportation of mature melanosomes to keratinocytes (Ernfors, 2010). Melanomagenesis is a stepwise metamorphic process in which normal melanocytes in the epidermis gradually transform into the vertical growth phase characteristic of malignant melanomas (Bevona et al., 2003). Cutaneous malignant melanoma is a highly aggressive and metastatic malignancy accounting for the majority of skin cancer-related deaths worldwide (Villanueva and Herlyn, 2008). Among several factors, exposure to UV light, melanocyte integrity, and melanocyte homeostatic mechanisms play important roles in the transformation of melanocytes into melanomas (Gupta et al., 2005; Rigel, 2008).

The dysregulation of miRNAs has been linked to either the suppression or progression of the initiation, differentiation, development, and prognostic biomarker of melanoma (Gaur et al., 2007; Mueller et al., 2009; Chan et al., 2011; Bonazzi et al., 2012; Poliseno et al., 2012; Kozubek et al., 2013; Guo et al., 2014; Hwang et al., 2014; Knoll et al., 2014; Sun et al., 2014; Liu et al., 


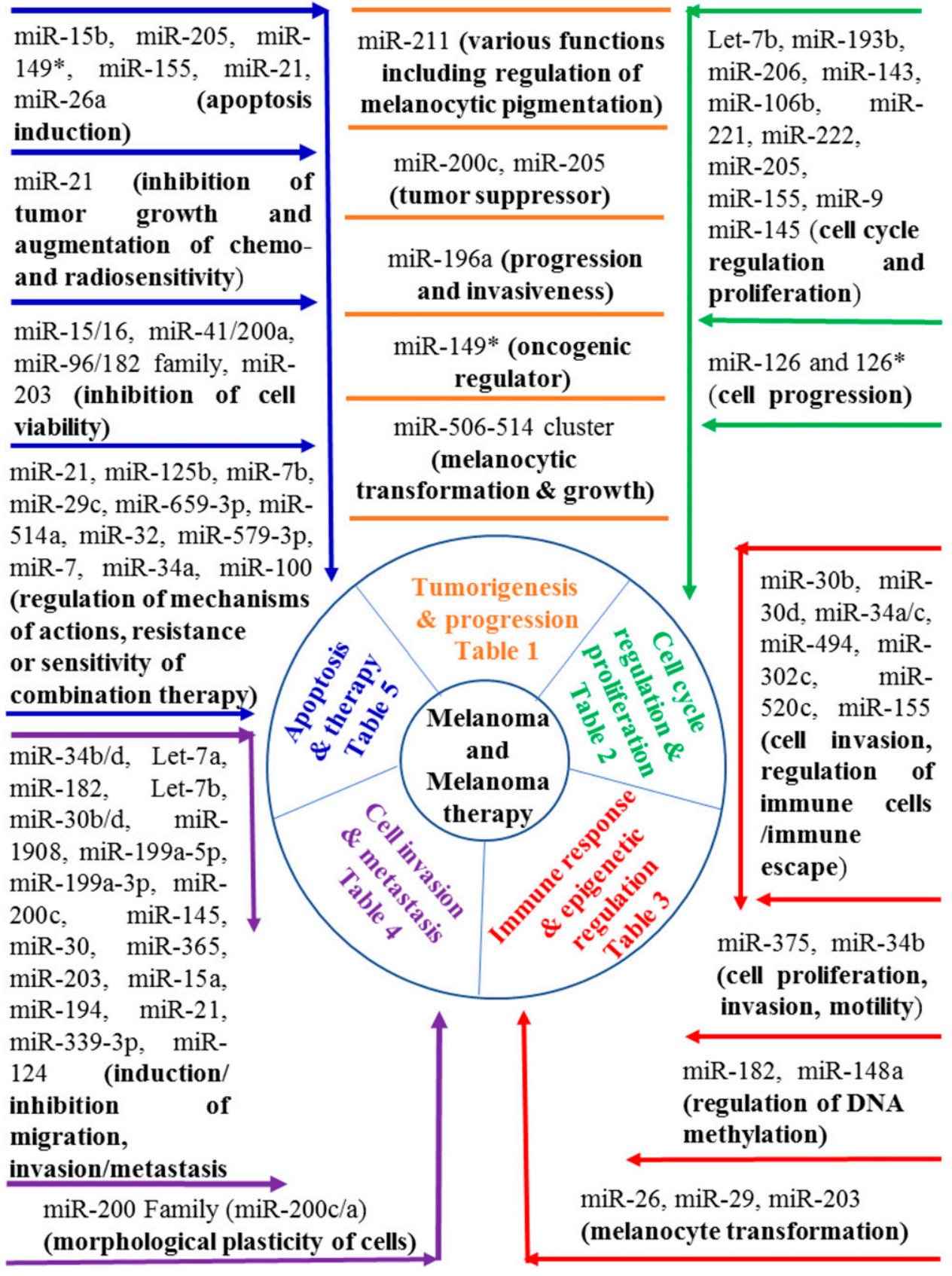

Fig. 1. Schematic representation of miRNA roles in melanoma and melanoma therapy.
2015; Saldanha et al., 2016a,b; Varamo et al., 2017) (Table 1). In miRNA systematic screens, miR-211 has been identified as the most differentially expressed miRNA between normal melanocytes, nonpigmented melanoma cell lines, and primary melanomas in patients (Xu et al., 2012; Bell et al., 2014). Using gene expression profiling of normal and melanoma cells, Bell et al. (2014) investigated relationships between transcription factors and miRNAs that are crucial for melanoma proliferation/ invasion and identified several miRNAs including miR-211, and its new target NUAKI. The ectopic expression of miR-211 in melanoma cells significantly inhibited its growth and invasion compared with parental cells, suggesting that miR-211 possesses tumor suppressor functions (Xu et al., 2012; Bell et al., 2014). This hypothesis was supported by findings that miR-211 is encoded by a region in the sixth intron of TRPM1, a candidate suppressor of melanoma metastasis (Mazar et al., 2010; Xu et al., 2012; Bell et al., 2014). Additionally, TRPM1 and miR-211 expressions were regulated by MITF, a transcription factor and master regulator of melanocyte development and function (Mazar et al., 2010). These findings indicate that the tumor suppressor activities of MITF and/or TRPM1 could be in part mediated by miR-211. Recently, several miR-211 target genes including RUNX2, IGF2R, TGFBR2, POU domain-containing transcription factor BRN2, and NFAT5 have been identified (Aftab et al., 2014). It has been proposed that miR-211 may also directly regulate melanocyte pigmentation and invasion since it is highly expressed in melanocytes and pigmented melanomas but not in nonpigmented melanomas (Aftab et al., 2014). Moreover, melanomas with greatly reduced miR-211 expression have been shown to possess highly invasive characteristics 
TABLE 1

miRNAs in melanomagenesis and progression

\begin{tabular}{|c|c|c|c|c|}
\hline miRNA & Function & Expression of miRNA & Target & Reference \\
\hline $\operatorname{miR}-211$ & $\begin{array}{l}\text { Tumor suppressor, regulation } \\
\text { of melanocytic pigmentation, } \\
\text { increased or decreased } \\
\text { invasiveness }\end{array}$ & $\begin{array}{l}\text { Upregulation or } \\
\text { downregulation }\end{array}$ & $\begin{array}{l}\text { NUAKI, RUNX2, TGFBR2, } \\
\text { BRN2, NFAT5, KCNMA1, } \\
\text { TRPM1, MITF }\end{array}$ & $\begin{array}{l}\text { Levy et al. (2010), Mazar et al. } \\
\text { (2010), Zhou et al. (2010), } \\
\text { Boyle et al. (2011), Xu et al. } \\
\text { (2012), Margue et al. (2013), } \\
\text { Bell et al. (2014) }\end{array}$ \\
\hline miR-200c, miR-205 & Tumor suppressor & $\begin{array}{l}\text { Differential } \\
\text { expression }\end{array}$ & & Xu et al. (2012) \\
\hline $\operatorname{miR}-196 a$ & Progression and invasiveness & Downregulation & $\begin{array}{l}\text { HOX-B7, bFGF, ETS-1, BMP-4, } \\
\text { HOX-C8, Cadherin-11, } \\
\text { Calponin-1, Osteopontin, }\end{array}$ & $\begin{array}{l}\text { Braig et al. (2010), Mueller and } \\
\text { Bosserhoff (2011) }\end{array}$ \\
\hline $\operatorname{miR}-149 *$ & Oncogenic regulator & Upregulation & GSK3 $\alpha$, Mcl-1 & Jin et al. (2011) \\
\hline $\begin{array}{l}\text { miR-506-514 cluster, } \\
\text { miR-218 }\end{array}$ & $\begin{array}{l}\text { Melanocyte transformation } \\
\text { (melanomagenesis) and } \\
\text { melanoma growth }\end{array}$ & Overexpression & MITF & $\begin{array}{l}\text { Streicher et al. (2012), } \\
\quad \text { Guo et al. (2014) }\end{array}$ \\
\hline
\end{tabular}

bFGF, basic fibroblast growth factor.

(Levy et al., 2010; Mazar et al., 2010; Margue et al., 2013). In contrast, miR-211 highly expressing melanoma cells possesses reduced invasive potential independent of metastatin, an inhibitor of tumor growth (Liu et al., 2001; Aftab et al., 2014; Bell et al., 2014). In the same context, miR-200c and miR-205 have been shown to be differentially expressed between benign nevi and primary or metastatic melanoma, and they act as tumor suppressors (Xu et al., 2012). Similarly, Braig et al. (2010) investigated miR-196a downregulation, which upregulated HOX-B7 and consequently stimulated basic fibroblast growth factor signaling, resulting in upregulation of ETS-1 transcription factor and BMP-4 expression, which play crucial roles in melanoma progression. Later, using the high-throughput miRNA expression profiling approach in melanoma cells and tissue samples, Mueller and Bosserhoff, 2011 showed that miR196a expression was significantly reduced in malignant lesions. Importantly, overexpression of miR-196a significantly reduced melanoma cell invasiveness (Mueller and Bosserhoff, 2011). In addition, HOX-C8, cadherin-11, calponin-1, and osteopontin were identified as miR-196a targets (Mueller and Bosserhoff, 2011). Moreover, miR-149*, a p53-responsive miRNA has been shown to be overexpressed in human metastatic melanoma isolates, and targets glycogen synthase kinase-3 alpha (GSK3 $\alpha$ ) to induce resistance of melanoma cells to apoptosis via increasing the expression of Mcl-1 (Jin et al., 2011). Furthermore, miR-506514 (a cluster of 14 miRNAs on the X chromosome) and miR-218 have been demonstrated to play crucial roles in initiating melanocyte transformation (melanomagenesis) and/or promoting melanoma growth (Streicher et al., 2012; Guo et al., 2014).

\section{miRNA and Regulation of Cell Cycle and Proliferation in Melanoma}

Since cell cycle regulation is controlled by several factors including cyclin-dependent kinases (CDKs), the E2F transcription factor, and proteins such as c-myc, p27 (a tumor suppressor protein that binds to and inhibits the function of the cyclin D1-CDK4 complex), as well as PTEN (Mamillapalli et al., 2001; Walter et al., 2002; Suryadinata et al., 2010), one can postulate that miRNAs that regulate cell proliferation might directly target these cell cycle regulators (Table 2). In this regard, let-7b miRNA has been shown to target cell cycle regulators since increased let-7b expression significantly decreases melanoma cell proliferation via reducing the expressions of CDK4, cyclin D1, and cyclin D3 (Schultz et al., 2008). Using miRNA microarrays, Chen et al. (2010) analyzed

TABLE 2

miRNAs in melanoma cell cycle regulation and proliferation

\begin{tabular}{|c|c|c|c|c|}
\hline miRNA & Function & Expression of miRNA & Target & Reference \\
\hline $\operatorname{miR}$ let-7b & $\begin{array}{l}\text { Cell cycle regulation and } \\
\text { proliferation }\end{array}$ & Upregulation & CDK4, cyclin D1, cyclin D3 & Schultz et al. (2008) \\
\hline $\operatorname{miR}-193 b$ & $\begin{array}{l}\text { Cell cycle regulation and } \\
\text { proliferation }\end{array}$ & Downregulation & Cyclin D1 & Chen et al. (2010) \\
\hline miR-206 & $\begin{array}{l}\text { G1 cell cycle arrest and } \\
\text { inhibition of proliferation }\end{array}$ & Downregulation & CDK4, cyclin D1, cyclin C & Georgantas et al. (2014) \\
\hline miR-143 & $\begin{array}{l}\text { G1 cell cycle arrest and induction } \\
\text { of apoptosis }\end{array}$ & Downregulation & Syn-1 & Li et al. (2016) \\
\hline $\operatorname{miR}-106 \mathrm{~b}$ & $\begin{array}{l}\text { G1 cell cycle arrest and } \\
\text { inhibition of growth }\end{array}$ & Downregulation & P21/WAF1/Cip1 & Prasad and Katiyar (2014) \\
\hline $\begin{array}{l}\operatorname{miR}-221 \text { and } \\
\text { miR-222 }\end{array}$ & Cell proliferation & $\begin{array}{l}\text { Downregulation } \\
\text { and upregulation }\end{array}$ & $\begin{array}{l}\text { PLZF, c-Kit, p27(Kip1)/ } \\
\text { CDKN1B }\end{array}$ & $\begin{array}{l}\text { Felicetti et al. (2008a,b), Igoucheva } \\
\text { and Alexeev (2009), Kanemaru } \\
\text { et al. (2011) }\end{array}$ \\
\hline miR-205 & Cell proliferation & Downregulation & $\mathrm{E} 2 \mathrm{~F} 1$ and E2F5 & Dar et al. (2011) \\
\hline miR-155 & Cell proliferation & Downregulation & SKI & Levati et al. (2011) \\
\hline miR-9 & Cell proliferation and migration & Downregulation & E-cadherin, NF-kB1-Snail1 & Liu et al. $(2012 a, b)$ \\
\hline miR-145 & $\begin{array}{l}\text { Suppression of cell proliferation } \\
\text { and migration }\end{array}$ & Downregulation & c-MYC & Noguchi et al. (2012) \\
\hline $\begin{array}{l}\operatorname{miR}-126 \text { and } \\
\text { miR-126* }\end{array}$ & Melanoma progression & Downregulation & ADAM9 MMP7 & Felli et al. (2013) \\
\hline
\end{tabular}


the expression of 470 miRNAs in benign nevi and metastatic melanoma tissues, and observed 31 differentially expressed miRNAs, of which miR-193b was significantly downregulated in melanoma tissues. Furthermore, overexpression of miR$193 \mathrm{~b}$ in Malme-3M melanoma cells resulted in inhibition of cell proliferation via downregulating 18 genes including cyclin D1 (CCND1) (Chen et al., 2010). Similarly, downregulation of miR-206, miR-143, or miR-106b expression has been correlated with reduced growth and migration/invasion of several melanoma cell lines mediated via G1 cell cycle arrest resulting in an inhibition of CDK4, cyclin D1, cyclin C, and syndecan-1 (Syn-1) or reactivation of p21/WAF1/Cip1 or as target genes (Georgantas et al., 2014; Li et al., 2016; Prasad and Katiyar, 2014). Since cell cycle regulation controls the proliferation of cells, miR-221 and miR-222 have been shown to directly modulate the in vitro and in vivo proliferation of melanoma cells via targeting multiple signaling pathways including c-Kit or $\mathrm{p} 27^{\mathrm{Kip} 1}$ and their circulating levels in malignant melanoma patients could be used as a new tumor marker (Felicetti et al., 2008a,b; Igoucheva and Alexeev, 2009; Kanemaru et al., 2011). Notably, miRNAs, including miR-205, miR-149, miR18b, miR-21, miR-203, and miR-26a have been documented to regulate cell cycle proteins in a cyclin-independent manner. In this regard, downregulation of miR-205 was reported in primary melanomas, and this regulates E2F1 and E2F5 transcription factors, which play crucial roles in the development of malignant melanoma (Nelson et al., 2006; Nelson and Weiss, 2008; Umemura et al., 2009; Dar et al., 2011). Levati et al. (2011) demonstrated that ectopic overexpression of miR155 significantly inhibited the proliferation of melanoma cells via inducing apoptosis. Similarly, Liu et al. (2012a) identified downregulation of miR-9 in metastatic melanomas compared with primary melanomas, and its overexpression significantly decreased the proliferation and migration of melanoma cells in an NF-kB1-dependent manner. Along similar lines, miR-145 expression was reported to be downregulated in canine melanoma cells and tissues and human melanoma cells. The ectopic expression of miR-145 significantly reduced the growth and migration of canine and human melanoma cells
(Noguchi et al., 2012). Felli et al. (2013) showed that miR-126 and $126^{*}$ expression was downregulated during melanoma progression and metalloproteases, domain 9 (ADAM9), and domain 7 (MMP7) were identified as direct targets of miR-126 and $126^{*}$, indicating their importance in melanoma progression.

\section{miRNA and Regulation of Melanoma Immune Responses}

In addition to regulating cell cycle, miRNAs have been demonstrated to influence the host immunity against melanoma (Table 3). In this regard, the ectopic expression of miR-30b and miR-30d has been shown to target GalNAc transferase GALNT7 to enhance melanoma metastasis via promoting invasion, increased synthesis of immunosuppressive cytokine IL-10, reduced immune cell activation, and recruitment, which resulted in induction of immunosuppression (Gaziel-Sovran et al., 2011). Similarly, miR-34a/c has been reported to regulate innate immune responses in melanoma cells via controlling ULBP2 expression, a stress-induced ligand of NKG2D (Heinemann et al., 2012). Since NKG2D detects early tumorigenesis, eliminates cytotoxic lymphocytes, and provides an innate barrier to tumor development, overexpression of miR-34 downregulated ULBP2 expression, and removal of ULBP2 ligand protected malignant melanoma cells from NKG2D-mediated immune surveillance (Heinemann et al., 2012). Similarly, upregulation of the NKG2D ligands MICA/B and ULBP2 has been reported to mediate natural killer cell-induced cytotoxicity of melanoma cells by $1,25(\mathrm{OH}) 2 \mathrm{D} 3$ treatment mediated partly via the downregulation of miR302c and miR-520c expression (Min et al., 2013). Since suppressive immunophenotypes such as myeloid-derived suppressor cells are involved in mediating immunosuppression and/or promoting tumor growth (Sahu et al., 2014a). Liu et al. (2012b) have shown that TGF- $\beta 1$-induced miR-494 expression in myeloid-derived suppressor cells favors the accumulation and functions of tumor-expanded myeloid-derived suppressor cells mediated by targeting PTEN and activation of the Akt pathway. Moreover, Arts et al. (2015) demonstrated the role of

TABLE 3

miRNAs in the regulation of immune responses and epigenetics in melanoma

\begin{tabular}{|c|c|c|c|c|}
\hline miRNA & Function & Expression of miRNA & Target & Reference \\
\hline $\begin{array}{l}\text { miR-30b and } \\
\text { miR-30d }\end{array}$ & $\begin{array}{l}\text { Cell invasion and Immune } \\
\text { suppression }\end{array}$ & Upregulation & GalNAc transferases & Gaziel-Sovran et al. (2011) \\
\hline $\begin{array}{l}\text { miR-34a and } \\
\text { miR-34c }\end{array}$ & Regulation of innate immunity & Upregulation & NKG2DL ULBP2 & Heinemann et al. (2012) \\
\hline $\operatorname{miR}-494$ & Tumor-expanded MDSCs & Upregulation & PTEN & Liu et al. (2012b) \\
\hline $\begin{array}{l}\text { miR-302c and } \\
\text { miR-520c }\end{array}$ & $\begin{array}{l}\text { Natural killer cell-mediated } \\
\text { toxicity to tumor cells }\end{array}$ & Downregulation & NKG2D, MICA/B, and ULBP2 & Min et al. (2013) \\
\hline $\operatorname{miR}-155$ & Melanoma immune escape & Upregulation & IL-1 $\beta$, MITF-M & Arts et al. (2015) \\
\hline miR-375 & $\begin{array}{l}\text { Cell proliferation, invasion, and } \\
\text { cell motility }\end{array}$ & Epigenetic regulation & $\begin{array}{l}\text { Minimal CpG island methylation } \\
\text { in melanocytes, keratinocytes, } \\
\text { normal skin and nevus } \\
\text { Hypermethylation of CpG island } \\
\text { in patients primary, regional, } \\
\text { distant and nodular metastatic } \\
\text { melanoma tissues }\end{array}$ & Mazar et al. (2011a) \\
\hline $\operatorname{miR}-34 b$ & Cell invasion and motility & Epigenetic regulation & $\mathrm{CpG}$ island methylation & Mazar et al. (2011b) \\
\hline miR-182 & Epigenetic modulation & Upregulation & CpG island hypermethylation & Liu et al. (2013a) \\
\hline $\operatorname{miR}-148 \mathrm{a}$ & Regulation of DNA methylation & Downregulation & TGIF2 & Tian et al. (2015) \\
\hline $\begin{array}{l}\text { miR-26, miR-29 } \\
\text { and miR-203 }\end{array}$ & $\begin{array}{l}\text { Melanocyte transformation/ } \\
\text { antioncogenic }\end{array}$ & Epigenetic regulation & Dnmt3b CREB1/MITF/RAB27a & $\begin{array}{l}\text { Gasque Schoof et al. (2015), } \\
\text { Noguchi et al. (2015, } \\
2016)\end{array}$ \\
\hline
\end{tabular}

MDSC, myeloid derived suppressor cell. 
miR-155 in targeting the novel mechanisms of melanoma immune escape in inflammatory microenvironment mediated via the modulation of IL- $1 \beta$-induced downregulation of endogenous MITF-M expression in melanoma cells.

\section{miRNA and Epigenetic Regulation of Melanoma}

Epigenetic refers to those biologic processes by which changes in phenotype or gene expression occur without changes in DNA sequences. Several miRNAs have been shown to regulate or be regulated by epigenetic modification in melanoma (de Unamuno et al., 2015) (Table 3). In this regard, Mazar et al. (2011a) have demonstrated that miR-375 epigenetically regulates the development of melanoma in patients. In this study, the authors have shown that $\mathrm{CpG}$ island methylation regulates miR-375 expression in WM1552C stage 3 melanoma cells following treatment with the demethylating agents 5-aza-2-deoxycytidine and 4-phenyl-butyrate (Mazar et al., 2011a). Methylation of miR$375 \mathrm{CpG}$ islands was stage dependent with significant levels in stage II and III melanoma tumors compared with stage I melanomas or benign melanocytes (Mazar et al., 2011a). In another study, the expression of miR-34b was shown to be regulated by increased methylation of $\mathrm{CpG}$ islands, and this was apparent in stage III and IV melanoma tumors compared with stage I and II melanomas, melanocytes, and keratinocytes (Mazar et al., 2011b). Similarly, epigenetic modulation has been shown to induce overexpression of miR-182 in human melanoma cells, and CpG islands upstream of mature miR-182 were found to be hyper-methylated in melanoma cells (Liu et al., 2013a). In addition, Tian et al., 2015 reported decreased expression of miR$148 \mathrm{a}$ in skin cancer patients when the TGIF2 gene was targeted. In this study, the authors found that DNA methylation regulated the expression and function of miR-148a, and they concluded that this miR-148a methylation could serve as an independent potential indicator/marker in the prognosis of skin cancer. However, due to the limitation of the number of samples and experimental conditions, as well as other unfavorable factors, further studies are still necessary (Tian et al., 2015). Importantly, Gasque Schoof et al. (2015) demonstrated the roles of miR-26, miR-29, and miR-203 in the regulation of epigenetic reprogramming, and the involvement of the Dnmt3a, Dnmt3b, Mecp2, and Ezh2 genes during melanocyte transformation. Similarly, DNA methylation of CpG islands upstream of the miR-203 coding region (MIR203) was detected in both human and canine melanoma cells as well as canine clinical specimens, but not in human normal melanocytes. The findings by Noguchi et al., 2015 indicated that demethylating MIR203 agents could be used as promising therapeutic targets for the treatment of human and canine melanomas. This same group later demonstrated that miR-203 functions as a common tumor suppressor miRNA in human and canine melanoma cells via its ability to directly target CREB1 and its downstream targets MITF and RAB27a (Noguchi et al., 2016).

\section{miRNAs in Melanoma Cell Invasion and Metastasis}

Metastasis of melanoma tumors to distal organs including the brain is a complex process requiring several stages from local tumor invasion to intra- and extravasation leading to the formation of macrometastases, which is the major cause of skin cancer-related mortality in the United States (Adler et al., 2017; Westphal et al., 2017) (Table 4). Several factors or signaling pathways have been shown to drive melanoma cell migration and invasion leading to metastasis including FSCN1, basigin, $\beta 3$-integrin, GALANT7, MARCKS, c-MET, STAT3, PTEN, and NFkB1 (Muramatsu and Miyauchi, 2003; Boukerche et al., 2007; Estrada-Bernal et al., 2009; ElsonSchwab et al., 2010; Yang et al., 2011; Chattopadhyay et al., 2012; Liu et al., 2013b; Li et al., 2016). Importantly, a wide array of miRNAs has been identified to target the key signaling pathways including those previously mentioned (Zhang et al., 2006). In this regard, Migliore et al. (2008) have shown that miR-34b/c acts as a suppressor of metastasis since ectopic expression of these miRNAs directly targets the protooncogene MET, leading to inhibition of MET-induced signal transduction and invasive behavior of melanoma cells. Given that enhanced expression of ITGB3 increases the invasiveness of melanoma cells (Seftor et al., 1992), let-7a has been shown to reduce the invasive potential of melanoma cells via negatively regulating ITGB3 expression (Müller and Bosserhoff, 2008). Similarly, miR-182, a frequently amplified miRNA in melanoma tumors compared with benign melanocytes has been shown to promote melanoma metastasis via repressing FOXO3 and MITF-M (Sequra et al., 2009). Downregulation of miR-182 impeded the invasion via inducing apoptosis, and enhanced expression of FOXO3 or MITF-M blocked miR-182induced proinvasive effects (Segura et al., 2009). While several miRNAs have been shown to either promote or reduce the invasiveness of melanoma cells, Elson-Schwab et al. (2010) demonstrated that expression of miR-200 family members does not suppress invasion but regulates morphologic plasticity or leads to a switch between modes of invasion of melanoma cells. The expression of miR-200c resulted in a higher proportion of cells adopting the rounded or amoeboid-like mode of invasion mediated via reduced expression of MARCKS, and miR-200a induced a protrusion-associated elongated mode of invasion via reduced actomyocin contractility (Elson-Schwab et al., 2010). Reduced let-7b expression in melanoma cells leads to increased metastases due to enhanced expression of basigin, an invasion-associated protein, and consequently enhanced expression of extracellular matrix metalloproteinases (Fu et al., 2011), while overexpression of let- $7 b$ results in reduced basigin and MMP-9 protein expression and decreased distant metastases (Fu et al., 2011). Along similar lines, Gaziel-Sovran et al. (2011) reported that expression of miR30b/30d in human melanoma positively correlated with the stage, metastatic potential, shorter time to recurrence, and reduced overall survival. Ectopic expression of miR-30b/30d in melanoma cells increased their metastatic behavior via direct targeting of GalNAc transferase GALNT7, which resulted in reduced immune cell activation and recruitment. In addition, Yang et al. (2011) demonstrated that the overexpression of miR-21 in human melanoma requires STAT-3 activation, and regulates the metastatic behavior of B16 melanoma cells via targeting tumor suppressor (PTEN and PDCD40) and antiproliferative (BTG2) proteins. Specific miRNAs, termed metastamirs, were reported to regulate the migration, invasion, and metastasis of melanoma cells, suggesting that they represent novel targets to inhibit melanoma progression (White et al., 2011; Segura et al., 2012). Moreover, miR-1908, miR-199a-5p, and miR-199a-3p have been shown to target ApoE, which leads to LRP1/LRP8-dependent melanoma metastasis 
TABLE 4

miRNAs in melanoma cell invasion and metastasis

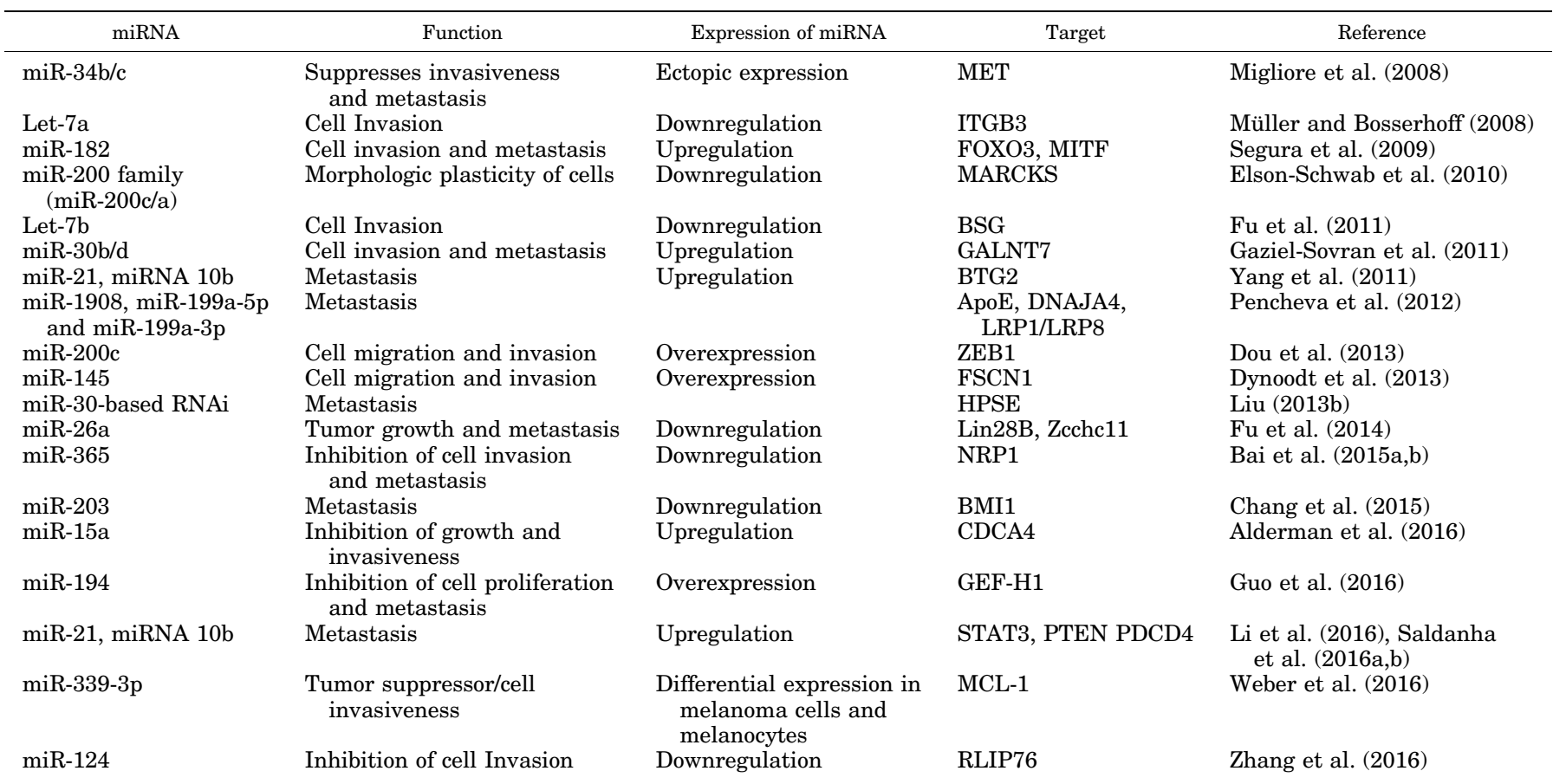

BSG, basigin; HPSE, heparanase; RNAi, RNA interference.

and angiogenesis (Pencheva et al., 2012). Similarly, overexpression of miR-200c (in CD44 + CD133 + cancer stem cells) and miR-145 has been demonstrated to downregulate ZEB1 or FSCN1, a known regulator of cell migration to inhibit the migration, invasion, and/or tumorigenicity of melanoma cells in vitro and in vivo (Dou et al., 2013; Dynoodt et al., 2013). Using miR-30-based short hairpin RNAs against heparanase and lentiviral approaches, it was reported that miRNAs (miR-30) targeting heparanase could be used as an effective RNA interference agent to suppress melanoma metastasis (Liu et al., 2013b). Interestingly, Fu et al. (2014) demonstrated the role of miR-26a in enhancing the biogenesis of other miRNAs, especially let-7 in various cancer models including melanoma via targeting Lin28B and Zcchc11, and suppressing tumor growth and metastasis. Recent studies have demonstrated that the downregulation of miR-365, miR-203, miR-124 and miR-10b or the overexpression/upregulation of miR-15a, miR-194, and miR-21 will inhibit the growth/proliferation, invasion, and/or metastasis of malignant melanoma cells via their abilities to target distinct signaling pathways such as neuropilin 1 (NRP1), BMI1, RLIP76, a stress-inducible non-ABC transporter, CDCA4, GEF-H1, STAT3, PTEN, and PDCD4 (Bai et al., 2015b; Chang et al., 2015; Alderman et al., 2016; Guo et al., 2016; Li et al., 2016; Saldanha et al., 2016a,b; Zhang et al., 2016). Importantly, the differential expression of miR-339-3p in melanoma cells and healthy melanocytes has been correlated with reduced invasion associated with decreased MCL1 expression (Weber et al., 2016)

\section{miRNA and Apoptotic Induction in Melanoma}

Multiple studies have highlighted the role of microRNAs, including miR-205, miR-155, miR-26a, miR-21, miR-15b, and miR-149* in apoptosis induction (Satzger et al., 2010, 2012;
Dar et al., 2011; Jin et al., 2011; Levati et al., 2011; Reuland et al., 2013; Jiao et al., 2015; Mao et al., 2017) (Table 5). In this regard, Satzger et al. (2010) determined the expression levels of 16 miRNAs in normal melanocytes versus 10 melanoma cell lines and FFPE tissues of 11 melanocytic nevi versus 16 melanomas. In their study, the levels of miR-15b and miR-210 were significantly upregulated, and miR-34a was significantly downregulated. However, upon further evaluation of these three miRNAs in 128 primary melanomas from patients with detailed clinical follow-up information, only miR-15b was found to be significantly associated with poor recurrence-free survival, and overall survival. The downregulation of miR-15b in two melanoma cell lines with higher miR-15b expression resulted in reduced tumor cell proliferation and increased apoptosis, indicating the important role of miR-15b in melanoma and associated poor prognosis and tumorigenesis (Satzger et al., 2010). In another study, reduced miR-205 expression was identified in melanoma cells compared with benign nevi (Dar et al., 2011). Further analysis showed that miR-205 targets E2F1 and reduces its expression by decreasing the proliferation via inducing apoptosis mediated through the activation of p73 family members in advanced malignant melanomas (Dar et al., 2011). Importantly, miR-149* was found to be directly regulated by p53, which targets glycogen synthase kinase-3 alpha to induce resistance of melanoma cells to apoptosis mediated via increased expression of Mcl-1 (Jin et al., 2011). In addition, downregulation of miR-155 was found to be downregulated, and its ectopic expression induces apoptosis via inhibition of SKI gene expression (Levati et al., 2011). Interestingly, miR-21 expression was reported to be significantly increased in primary and malignant melanoma tissues and melanoma cells compared with benign nevi, normal skin, and melanocytic cell preparation, and that 
TABLE 5

miRNAs in melanoma apoptosis and melanoma therapy

\begin{tabular}{|c|c|c|c|c|}
\hline miRNA & Function & Expression of miRNA & Target & Reference \\
\hline $\begin{array}{l}\text { miR-15b, miR-205, } \\
\text { miR-149*, miR-155, } \\
\text { miR-21, miR-26a }\end{array}$ & Apoptosis induction & $\begin{array}{l}\text { Upregulation of } 15 \mathrm{~b}, 149^{*} \\
\text { and } 21 \text { Downregulation } \\
\text { of } 155,205 \text {, and } 26 \mathrm{a}\end{array}$ & $\begin{array}{l}\text { E2F1 (205), SODD } \\
\text { (26a), GSK-3 } \alpha \text { (149*), } \\
\text { SKI (155), PDCD4 } \\
\text { (21), SPRY1 (21) and } \\
\text { PTEN (21) }\end{array}$ & $\begin{array}{l}\text { Satzger et al. (2010, 2012), Dar } \\
\text { et al. (2011), Jin et al. (2011), } \\
\text { Levati et al. (2011), Reuland } \\
\text { et al. (2013), Jiao et al. } \\
\text { (2015), Mao et al. (2017) }\end{array}$ \\
\hline $\operatorname{miR}-21$ & $\begin{array}{l}\text { Inhibition of growth and } \\
\text { augmentation of chemo- } \\
\text { and radiosensitivity }\end{array}$ & Upregulation & $\mathrm{Bax} / \mathrm{Bcl}-2$ ratio & Jiang et al. (2012) \\
\hline $\begin{array}{l}\text { miR-15/16, miR- } \\
\text { 41/200a, miR- } \\
\text { 96/182 family of } \\
\text { miRNAs and miR- } \\
203\end{array}$ & Inhibition of cell viability & Downregulation & Survivin & Poell et al. (2012) \\
\hline $\begin{array}{l}\text { miR-125b, miR-7b, } \\
\text { miR-29c }\end{array}$ & $\begin{array}{l}\text { Regulation of mechanisms } \\
\text { of action of Temsirolimus } \\
\text { and Bevacizumab } \\
\text { combination }\end{array}$ & $\begin{array}{l}\text { Differential expression } \\
\text { after treatment with } \\
\text { temsirolimus and } \\
\text { bevacizumab } \\
\text { combination }\end{array}$ & $\begin{array}{r}\text { AKT, CCND1, } \\
\text { DNMT3A/B }\end{array}$ & Wagenseller et al. 2013 \\
\hline miR-659-3p & $\begin{array}{l}\text { Predicts clinical outcome of } \\
\text { carboplatin/paclitaxel- } \\
\text { based therapy }\end{array}$ & $\begin{array}{l}\text { Differential expression } \\
\text { based on PFS }\end{array}$ & NFIX & Villaruz et al. (2015) \\
\hline $\operatorname{miR}-514 a$ & $\begin{array}{l}\text { Modulates BRAFi } \\
\text { sensitivity }\end{array}$ & Overexpression & NF1 & Stark et al. (2015) \\
\hline $\operatorname{miR}-32$ & $\begin{array}{l}\text { Tumor suppressor and } \\
\text { exhibit synergistic effects } \\
\text { with vemurafenib }\end{array}$ & Poor expression & MCL-1 & Mishra et al. (2016) \\
\hline miR-579-3p & $\begin{array}{l}\text { Resistance to targeted } \\
\text { therapy }\end{array}$ & $\begin{array}{l}\text { Low expression } \\
\quad \text { (downregulation) }\end{array}$ & BRAF, MDM2 & Fattore et al. (2016) \\
\hline $\operatorname{miR}-7$ & $\begin{array}{l}\text { Reversal of resistance to } \\
\text { targeted therapy }\end{array}$ & Downregulation & EGFR/IGF-1R/CRAF & Sun et al. (2016) \\
\hline $\begin{array}{l}\text { miR-34a, miR-100 and } \\
\text { miR-125b }\end{array}$ & $\begin{array}{l}\text { Restoration of resistance to } \\
\text { vemurafenib }\end{array}$ & $\begin{array}{l}\text { High expression } \\
\text { (upregulation) }\end{array}$ & CCL-2 & Vergani et al. (2016) \\
\hline
\end{tabular}

GSK-3 $\alpha$, glycogen synthase kinase-3 alpha; PFS, progression free survival; SODD, silencer of death domain.

downregulation of miR-21 in melanoma cells induces apoptosis without significantly affecting cell proliferation or via targeting PDCD4 (Satzger et al., 2012; Jiao et al., 2015). Moreover, miR-26a was found to be significantly downregulated in human melanoma cell lines compared with primary melanocytes, and overexpression of miR-26a resulted in significant and rapid cell death and repressed silencer of death domain expression that rescued melanoma cells from undergoing apoptosis, suggesting miR-26a as a potential therapeutic molecule in the treatment of melanoma (Reuland et al., 2013). Furthermore, miR-21 was reported to also regulate the ERK/NF-kB pathway, and miR-21 inhibitors inhibit the proliferation, migration, and invasion of A375 human melanoma cells via inducing increased apoptosis by targeting SPRY1, PDCD4, and PTEN (Mao et al., 2017).

\section{miRNA and Melanoma Therapy}

Malignant melanoma often develops resistance to most standard chemotherapeutic agents and radiation therapy (Terando et al., 2003). While new targeted therapies such as vemurafenib, which targets a BRAFV600-activating mutant kinase, have shown initial promising anti-tumor responses in melanoma patients, tumor resistance remains a significant therapeutic challenge (Wagle et al., 2011; Sosman et al., 2012; Kim et al., 2016; Boukari et al., 2017; Zhao et al., 2017). Among several oncogenic signaling pathways that contribute to tumor resistance, our recent studies have shown that plateletactivating factor/receptor-mediated pathways play a crucial role in the development of melanoma and negatively impact the efficacy of standard chemotherapy and radiation therapy in preclinical and clinical studies including melanoma (Sahu et al., 2012, 2014a,b, 2015, 2016; Hackler et al., 2014). Thus, further investigation of molecular mechanisms underlying melanoma development and/or therapeutic resistance is required to design new strategies to improve the clinical outcomes in melanoma patients. Despite various reports correlating miRNA involvement with or without BRAFmutated melanoma tumors and/or therapies in preclinical and clinical studies (Caramuta et al., 2010; Shi et al., 2014; Lankenau et al., 2015; Pinto et al., 2015; Foth et al., 2016; Mannavola et al., 2016; Saldanha et al., 2016a,b), more research is needed to develop sensitive and specific molecular tests to identify novel miRNAs that are modulated in response to resistance to standard melanoma therapies (Table 5). In a recent review, Fattore et al. (2017) highlighted the roles of miRNAs in inducing the development of resistance to BRAF and MEK inhibitors. Importantly, Kozar et al. (2017) identified the differential expression of several new and previously reported miRNAs in BRAF inhibitor-resistant (vemurafenib and dabrafenib) melanoma cells. In addition, Jiang et al. (2012) reported that miR-21 status was an independent prognostic factor in cutaneous melanoma patients. Importantly, antisense-mediated miR-21 silencing inhibited melanoma growth via increasing apoptosis and also enhanced the chemo- or radiosensitivity of human cutaneous melanoma cells, suggesting its potential in the treatment of human cutaneous malignant melanoma (Jiang et al., 2012). Using functional assays, Poell et al. (2012) highlighted the importance of miR-15/16, miR-141/200a, miR-96/182, and miR-203 
as potent inhibitors of melanoma cell proliferation since ectopic expression of these miRNAs resulted in long-term inhibition of melanoma cell expansion, both in vitro and in vivo. This study provided a comprehensive interrogation of miRNAs that interfere with melanoma cell proliferation and viability, and offered a selection of miRNAs that are promising candidates in melanoma therapy (Poell et al., 2012). Wagenseller et al. (2013) studied global miRNA expression profiles using microarrays in melanoma tissues from combination-targeted therapy of temsirolimus- and bevacizumab-treated patients, and detected significant upregulation of 15 miRNAs in treated versus nontreated melanoma tissues, 12 of which possess tumor suppressor functions via their ability to target 15 different oncogenes. Of these miRNAs, miR-125b, miR-7b, and miR-29c were differentially expressed after temsirolimus and bevacizumab combination treatment. Similarly, differential expression of miR-659-3p based on progression-free survival was reported to predict the clinical outcome of carboplatin/paclitaxelbased therapy in metastatic melanoma patients (Villaruz et al., 2015). In particular, miR-514a, which plays an important role in initiating melanocyte transformation and promotion of melanoma growth, has been reported to modulate the sensitivity of BRAF-targeted therapy via regulating the tumor suppressor NF1 gene (Stark et al., 2015). These findings indicate that these miRNAs could serve as attractive candidates for melanoma intervention (Wagenseller et al., 2013; Stark et al., 2015; Villaruz et al., 2015). In addition, miR-32 replacement therapy as a single agent has been demonstrated to suppress the growth of melanoma tumors in preclinical models via targeting MCL-1 and to exhibit synergistic effects with vemurafenib (Mishra et al., 2016). Moreover, while miR579-3p has been shown to be associated with the development of melanoma resistance (Fattore et al., 2016), miR-7, miR$34 \mathrm{a}$, miR-100, and miR-125b have been demonstrated to reverse/restore melanoma resistance (Sun et al., 2016; Vergani et al., 2016) in targeted therapies via targeting distinct signaling pathways. Importantly, recent studies have implicated the functions and clinical significance of long noncoding RNAs in melanoma (Aftab et al., 2014; Richtig et al., 2017). Thus, future combinatorial approaches should focus on oncogenes that can be targeted by miRNAs and long noncoding RNAs in cancer detection and treatment, including melanoma.

\section{Conclusions}

From its discovery to the present, miRNAs have represented a paradigm shift in scientific research. miRNAs may assist in the diagnosis and early detection of melanoma recurrence, and in predicting patient's outcomes/responses to therapies. Thus, the development of miRNAs as accurate progression risk biomarkers would greatly enhance the clinical management of melanoma.

\section{Authorship Contributions}

Wrote or contributed to the writing of the manuscript: Thyagarajan, Shaban, Sahu.

\section{References}

Adler NR, Haydon A, McLean CA, Kelly JW, and Mar VJ (2017) Metastatic pathways in patients with cutaneous melanoma. Pigment Cell Melanoma Res 30:13-27.

Aftab MN, Dinger ME, and Perera RJ (2014) The role of microRNAs and long noncoding RNAs in the pathology, diagnosis, and management of melanoma. Arch Biochem Biophys 563:60-70.
Alderman C, Sehlaoui A, Xiao Z, and Yang Y (2016) MicroRNA-15a inhibits the growth and invasiveness of malignant melanoma and directly targets on CDCA4 gene. Tumour Biol 37:13941-13950.

Ambros V (2004) The functions of animal microRNAs. Nature 431:350-355.

Andorfer CA, Necela BM, Thompson EA, and Perez EA (2011) MicroRNA signatures: clinical biomarkers for the diagnosis and treatment of breast cancer. Trends Mol Med 17:313-319.

Arts N, Cané S, Hennequart M, Lamy J, Bommer G, Van den Eynde B, and De Plaen E (2015) microRNA-155, induced by interleukin- $1 \beta$, represses the expression of microphthalmia-associated transcription factor (MITF-M) in melanoma cells. PLoS One 10:e122517.

Bai J, Zhang Z, Li X, and Liu H (2015b) MicroRNA-365 inhibits growth, invasion and metastasis of malignant melanoma by targeting NRP1 expression. Int J Clin Exp Pathol 8:4913-4922.

Bartel DP (2004) MicroRNAs: genomics, biogenesis, mechanism, and function. Cell 116:281-297.

Bell RE, Khaled M, Netanely D, Schubert S, Golan T, Buxbaum A, Janas MM, Postolsky B, Goldberg MS, Shamir R, et al. (2014) Transcription factor/microRNA axis blocks melanoma invasion program by miR-211 targeting NUAK1. $J$ Invest Dermatol 134:441-451.

Berezikov E, Cuppen E, and Plasterk RH (2006) Approaches to microRNA discovery. Nat Genet 38 (Suppl):S2-S7.

Berezikov E, Guryev V, van de Belt J, Wienholds E, Plasterk RH, and Cuppen E (2005) Phylogenetic shadowing and computational identification of human microRNA genes. Cell 120:21-24.

Bevona C, Goggins W, Quinn T, Fullerton J, and Tsao H (2003) Cutaneous melanomas associated with nevi. Arch Dermatol 139:1620-1624, discussion 1624

Bonazzi VF, Stark MS, and Hayward NK (2012) MicroRNA regulation of melanoma progression. Melanoma Res 22:101-113.

Boukari F, Dugourd PM, Chassang M, Mondot L, Passeron T, Lacour JP, and Montaudie H (2017) Posterior reversible encephalopathy syndrome due to combination of vemurafenib and cobimetinib for metastatic melanoma. Pigment Cell Melanoma Res 30:262-264.

Boukerche H, Su ZZ, Emdad L, Sarkar D, and Fisher PB (2007) mda-9/Syntenin regulates the metastatic phenotype in human melanoma cells by activating nuclear factor- $\kappa \mathrm{B}$. Cancer Res 67:1812-1822.

Boyle GM, Woods SL, Bonazzi VF, Stark MS, Hacker E, Aoude LG, Dutton-Regester $\mathrm{K}$, Cook AL, Sturm RA, and Hayward NK (2011) Melanoma cell invasiveness is regulated by miR-211 suppression of the BRN2 transcription factor. Pigment Cell Melanoma Res 24:525-537.

Braig S, Mueller DW, Rothhammer T, and Bosserhoff AK (2010) MicroRNA miR$196 \mathrm{a}$ is a central regulator of HOX-B7 and BMP4 expression in malignant melanoma. Cell Mol Life Sci 67:3535-3548.

Brennecke J, Stark A, Russell RB, and Cohen SM (2005) Principles of microRNAtarget recognition. PLoS Biol 3:e85.

Caramuta S, Egyházi S, Rodolfo M, Witten D, Hansson J, Larsson C, and Lui WO (2010) MicroRNA expression profiles associated with mutational status and survival in malignant melanoma. J Invest Dermatol 130:2062-2070.

Chan E, Patel R, Nallur S, Ratner E, Bacchiocchi A, Hoyt K, Szpakowski S, Godshalk S, Ariyan S, Sznol M, et al. (2011) MicroRNA signatures differentiate melanoma subtypes. Cell Cycle 10:1845-1852.

Chang X, Sun Y, Han S, Zhu W, Zhang H, and Lian S (2015) MiR-203 inhibits melanoma invasive and proliferative abilities by targeting the polycomb group gene BMI1. Biochem Biophys Res Commun 456:361-366.

Chattopadhyay C, Ellerhorst JA, Ekmekcioglu S, Greene VR, Davies MA, and Grimm EA (2012) Association of activated c-Met with NRAS-mutated human melanomas. Int $J$ Cancer 131:E56-E65.

Chen J, Feilotter HE, Paré GC, Zhang X, Pemberton JG, Garady C, Lai D, Yang X and Tron VA (2010) MicroRNA-193b represses cell proliferation and regulates cyclin D1 in melanoma. Am J Pathol 176:2520-2529.

Chiou TJ (2007) The role of microRNAs in sensing nutrient stress. Plant Cell Environ 30:323-332.

Cortez MA, Bueso-Ramos C, Ferdin J, Lopez-Berestein G, Sood AK, and Calin GA (2011) MicroRNAs in body fluids-the mix of hormones and biomarkers. Nat Rev Clin Oncol 8:467-477.

Dar AA, Majid S, de Semir D, Nosrati M, Bezrookove V, and Kashani-Sabet M (2011) miRNA-205 suppresses melanoma cell proliferation and induces senescence via regulation of E2F1 protein. J Biol Chem 286:16606-16614.

de Unamuno B, Palanca S, and Botella R (2015) Update on melanoma epigenetics. Curr Opin Oncol 27:420-426.

Dou J, He XF, Cao WH, Zhao FS, Wang XY, Liu YR, and Wang J (2013) Overexpression of microRna-200c in CD44+CD133+ CSCS inhibits the cellular migratory and invasion as well as tumorigenicity in mice. Cell Mol Biol (Noisy-legrand) (Suppl 59):OL1861-OL1868.

Dynoodt P, Speeckaert R, De Wever O, Chevolet I, Brochez L, Lambert J, and Van Gele M (2013) miR-145 overexpression suppresses the migration and invasion of metastatic melanoma cells. Int $J$ Oncol 42:1443-1451.

Ernfors P (2010) Cellular origin and developmental mechanisms during the formation of skin melanocytes. Exp Cell Res 316:1397-1407.

Elson-Schwab I, Lorentzen A, and Marshall CJ (2010) MicroRNA-200 family members differentially regulate morphological plasticity and mode of melanoma cell invasion. PLoS One 5:e13176.

Estrada-Bernal A, Gatlin JC, Sunpaweravong S, and Pfenninger KH (2009) Dynamic adhesions and MARCKS in melanoma cells. J Cell Sci 122:2300-2310.

Fattore L, Costantini S, Malpicci D, Ruggiero CF, Ascierto PA, Croce CM, Mancini R, and Ciliberto G (2017) MicroRNAs in melanoma development and resistance to target therapy. Oncotarget 8:22262-22278.

Fattore L, Mancini R, Acunzo M, Romano G, Laganà A, Pisanu ME, Malpicci D, Madonna G, Mallardo D, Capone M, et al. (2016) miR-579-3p controls melanoma progression and resistance to target therapy. Proc Natl Acad Sci USA 113:E5005-E5013. 
Felicetti F, Errico MC, Bottero L, Segnalini P, Stoppacciaro A, Biffoni M, Felli N, Mattia G, Petrini M, Colombo MP, et al. (2008a) The promyelocytic leukemia zinc finger-microRNA-221/-222 pathway controls melanoma progression through multiple oncogenic mechanisms. Cancer Res 68:2745-2754.

Felicetti F, Errico MC, Segnalini P, Mattia G, and Carè A (2008b) MicroRNA-221 and -222 pathway controls melanoma progression. Expert Rev Anticancer Ther 8 : 1759-1765.

Felli N, Felicetti F, Lustri AM, Errico MC, Bottero L, Cannistraci A, De Feo A, Petrini M, Pedini F, Biffoni M, et al. (2013) miR-126\&126* restored expressions play a tumor suppressor role by directly regulating ADAM9 and MMP7 in melanoma. PLoS One 8:e56824.

Foth M, Wouters J, de Chaumont C, Dynoodt P, and Gallagher WM (2016) Prognostic and predictive biomarkers in melanoma: an update. Expert Rev Mol Diagn 16: $223-237$.

Friedman RC, Farh KK, Burge CB, and Bartel DP (2009) Most mammalian mRNAs are conserved targets of microRNAs. Genome Res 19:92-105.

Fu TY, Chang CC, Lin CT, Lai CH, Peng SY, Ko YJ, and Tang PC (2011) Let-7bmediated suppression of basigin expression and metastasis in mouse melanoma cells. Exp Cell Res 317:445-451.

Fu X, Meng Z, Liang W, Tian Y, Wang X, Han W, Lou G, Wang X, Lou F, Yen Y, et al (2014) miR-26a enhances miRNA biogenesis by targeting Lin28B and Zcchc11 to suppress tumor growth and metastasis. Oncogene 33:4296-4306.

Gasque Schoof CR, Izzotti A, Jasiulionis MG, and Vasques LdosR (2015) The roles of miR-26, miR-29, and miR-203 in the silencing of the epigenetic machinery during melanocyte transformation. BioMed Res Int 2015:634749.

Gaur A, Jewell DA, Liang Y, Ridzon D, Moore JH, Chen C, Ambros VR, and Israel MA (2007) Characterization of microRNA expression levels and their biologica correlates in human cancer cell lines. Cancer Res 67:2456-2468.

Gaziel-Sovran A, Segura MF, Di Micco R, Collins MK, Hanniford D, Vega-Saenz de Miera E, Rakus JF, Dankert JF, Shang S, Kerbel RS, et al. (2011) miR-30b/30d regulation of GalNAc transferases enhances invasion and immunosuppression during metastasis. Cancer Cell 20:104-118.

Georgantas RW, III, Streicher K, Luo X, Greenlees L, Zhu W, Liu Z, Brohawn P, Morehouse C, Higgs BW, Richman L, et al. (2014) MicroRNA-206 induces G1 arrest in melanoma by inhibition of CDK4 and Cyclin D. Pigment Cell Melanoma Res 27: $275-286$

Griffiths-Jones S, Saini HK, van Dongen S, and Enright AJ (2008) miRBase: tools for microRNA genomics. Nucleic Acids Res 36:D154-D158.

Guo B, Hui Q, Zhang Y, Chang P, and Tao K (2016) miR-194 is a negative regulator of GEF-H1 pathway in melanoma. Oncol Rep 36:2412-2420

Guo H, Ingolia NT, Weissman JS, and Bartel DP (2010) Mammalian microRNAs predominantly act to decrease target mRNA levels. Nature 466:835-840.

Guo J, Zhang JF, Wang WM, Cheung FW, Lu YF, Ng CF, Kung HF, and Liu WK (2014) MicroRNA-218 inhibits melanogenesis by directly suppressing microphthalmia-associated transcription factor expression. RNA Biol 11:732-741.

Gupta PB, Kuperwasser C, Brunet JP, Ramaswamy S, Kuo WL, Gray JW, Naber SP, and Weinberg RA (2005) The melanocyte differentiation program predisposes to metastasis after neoplastic transformation. Nat Genet 37:1047-1054.

Hackler PC, Reuss S, Konger RL, Travers JB, and Sahu RP (2014) Systemic plateletactivating factor receptor activation augments experimental lung tumor growth and metastasis. Cancer Growth Metastasis 7:27-32.

Hall JS, Taylor J, Valentine HR, Irlam JJ, Eustace A, Hoskin PJ, Miller CJ, and West CM (2012) Enhanced stability of microRNA expression facilitates classification of FFPE tumour samples exhibiting near total mRNA degradation. $\mathrm{Br} J$ Cancer 107:684-694.

Heinemann A, Zhao F, Pechlivanis S, Eberle J, Steinle A, Diederichs S, Schadendorf D, and Paschen A (2012) Tumor suppressive microRNAs miR-34a/c control cancer cell expression of ULBP2, a stress-induced ligand of the natural killer cell receptor NKG2D. Cancer Res 72:460-471.

Holtz J and Pasquinelli AE (2009) Uncoupling of lin-14 mRNA and protein repression by nutrient deprivation in Caenorhabditis elegans. RNA 15:400-405.

Hwang HW, Baxter LL, Loftus SK, Cronin JC, Trivedi NS, Borate B, and Pavan WJ (2014) Distinct microRNA expression signatures are associated with melanoma subtypes and are regulated by HIF1A. Pigment Cell Melanoma Res 27:777-787.

Igoucheva O and Alexeev V (2009) MicroRNA-dependent regulation of cKit in cutaneous melanoma. Biochem Biophys Res Commun 379:790-794.

Jiang L, Lv X, Li J, Li J, Li X, Li W, and Li Y (2012) The status of microRNA-21 expression and its clinical significance in human cutaneous malignant melanoma. Acta Histochem 114:582-588.

Jiao J, Fan Y, and Zhang Y (2015) Expression and clinicopathological significance of microRNA-21 and programmed cell death 4 in malignant melanoma. J Int Med Res 43:672-678.

Jin L, Hu WL, Jiang CC, Wang JX, Han CC, Chu P, Zhang LJ, Thorne RF, Wilmott J, Scolyer RA, et al. (2011) MicroRNA-149*, a p53-responsive microRNA, functions as an oncogenic regulator in human melanoma. Proc Natl Acad Sci USA 108 15840-15845.

Kanemaru H, Fukushima S, Yamashita J, Honda N, Oyama R, Kakimoto A, Masuguchi S, Ishihara T, Inoue Y, Jinnin M, et al. (2011) The circulating microRNA-221 level in patients with malignant melanoma as a new tumor marker. J Dermatol Sci 61:187-193.

Karius T, Schnekenburger M, Dicato M, and Diederich M (2012) MicroRNAs in cancer management and their modulation by dietary agents. Biochem Pharmacol 83:1591-1601.

Kim HK, Lee S, Kim K, Heo MH, Lee H, Cho J, Kim NK, Park W, Lee SJ, Kim JH, et al. (2016) Efficacy of BRAF inhibitors in Asian metastatic melanoma patients: potential implications of genomic sequencing in BRAF-mutated melanoma. Transl Oncol 9:557-564.

Knoll S, Fürst K, Kowtharapu B, Schmitz U, Marquardt S, Wolkenhauer O, Martin $\mathrm{H}$, and Pützer BM (2014) E2F1 induces miR-224/452 expression to drive EMT through TXNIP downregulation. EMBO Rep 15:1315-1329.
Kozar I, Cesi G, Margue C, Philippidou D, and Kreis S (2017) Impact of BRAF kinase inhibitors on the miRNomes and transcriptomes of melanoma cells. Biochim Biophys Acta [published ahead of print].

Kozubek J, Ma Z, Fleming E, Duggan T, Wu R, Shin DG, and Dadras SS (2013) Indepth characterization of microRNA transcriptome in melanoma. PLoS One 8: e72699.

Lages E, Ipas H, Guttin A, Nesr H, Berger F, and Issartel JP (2012) MicroRNAs: molecular features and role in cancer. Front Biosci (Landmark Ed) 17:2508-2540. Lankenau MA, Patel R, Liyanarachchi S, Maharry SE, Hoag KW, Duggan M, Walker CJ, Markowitz J, Carson WE, III, Eisfeld AK, et al. (2015) MicroRNA-3151 inactivates TP53 in BRAF-mutated human malignancies. Proc Natl Acad Sci USA 112 E6744-E6751.

Lee RC, Feinbaum RL, and Ambros V (1993) The C. elegans heterochronic gene lin-4 encodes small RNAs with antisense complementarity to lin-14. Cell 75:843-854. Leung AK and Sharp PA (2010) MicroRNA functions in stress responses. Mol Cell 40 $205-215$.

Levati L, Pagani E, Romani S, Castiglia D, Piccinni E, Covaciu C, Caporaso P, Bondanza S, Antonetti FR, Bonmassar E, et al. (2011) MicroRNA-155 targets the SKI gene in human melanoma cell lines. Pigment Cell Melanoma Res 24 $538-550$

Levy C, Khaled M, Iliopoulos D, Janas MM, Schubert S, Pinner S, Chen PH, Li S, Fletcher AL, Yokoyama S, et al. (2010) Intronic miR-211 assumes the tumor suppressive function of its host gene in melanoma. Mol Cell 40:841-849.

Li H, Yuan SM, Yang M, Zha H, Li XR, Sun H, Duan L, Gu Y, Li AF, Weng YG, et al. (2016) High intensity focused ultrasound inhibits melanoma cell migration and metastasis through attenuating microRNA-21-mediated PTEN suppression. Oncotarget 7:50450-50460.

Liu N, Lapcevich RK, Underhill CB, Han Z, Gao F, Swartz G, Plum SM, Zhang L, and Green SJ (2001) Metastatin: a hyaluronan-binding complex from cartilage that inhibits tumor growth. Cancer Res 61:1022-1028.

Liu R, Xie H, Luo C, Chen Z, Zhou X, Xia K, Chen X, Zhou M, Cao P, Cao K, et al. (2015) Identification of FLOT2 as a novel target for microRNA-34a in melanoma. $J$ Cancer Res Clin Oncol 141:993-1006.

Liu S, Howell PM, and Riker AI (2013a) Up-regulation of miR-182 expression after epigenetic modulation of human melanoma cells. Ann Surg Oncol 20:1745-1752.

Liu S, Kumar SM, Lu H, Liu A, Yang R, Pushparajan A, Guo W, and Xu X (2012a) MicroRNA-9 up-regulates E-cadherin through inhibition of NF- $\kappa$ B1-Snail1 pathway in melanoma. $J$ Pathol 226:61-72.

Liu XY, Tang QS, Chen HC, Jiang XL, and Fang H (2013b) Lentiviral miR30-based RNA interference against heparanase suppresses melanoma metastasis with lower liver and lung toxicity. Int J Biol Sci 9:564-577.

Liu Y, Lai L, Chen Q, Song Y, Xu S, Ma F, Wang X, Wang J, Yu H, Cao X, et al. (2012b) MicroRNA-494 is required for the accumulation and functions of tumorexpanded myeloid-derived suppressor cells via targeting of PTEN. J Immunol 188: $5500-5510$

Lorenzen J, Kumarswamy R, Dangwal S, and Thum T (2012) MicroRNAs in diabetes and diabetes-associated complications. RNA Biol 9:820-827.

Lynn FC (2009) Meta-regulation: microRNA regulation of glucose and lipid metabolism. Trends Endocrinol Metab 20:452-459.

Mamillapalli R, Gavrilova N, Mihaylova VT, Tsvetkov LM, Wu H, Zhang H, and Sun $H$ (2001) PTEN regulates the ubiquitin-dependent degradation of the CDK inhibitor p2 $7^{\mathrm{KIP} 1}$ through the ubiquitin E3 ligase SCF ${ }^{\mathrm{SKP} 2}$. Curr Biol 11:263-267.

Mannavola F, Tucci M, Felici C, Stucci S, and Silvestris F (2016) miRNAs in melanoma: a defined role in tumor progression and metastasis. Expert Rev Clin Immunol 12:79-89.

Mao XH, Chen M, Wang Y, Cui PG, Liu SB, and Xu ZY (2017) MicroRNA-21 regulates the ERK/NF- $\kappa \mathrm{B}$ signaling pathway to affect the proliferation, migration, and apoptosis of human melanoma A375 cells by targeting SPRY1, PDCD4, and PTEN Mol Carcinog 56:886-894.

Margue C, Philippidou D, Reinsbach SE, Schmitt M, Behrmann I, and Kreis S (2013) New target genes of MITF-induced microRNA-211 contribute to melanoma cell invasion. PLoS One 8:e73473.

Mazar J, DeBlasio D, Govindarajan SS, Zhang S, and Perera RJ (2011a) Epigenetic regulation of microRNA-375 and its role in melanoma development in humans. FEBS Lett 585:2467-2476.

Mazar J, DeYoung K, Khaitan D, Meister E, Almodovar A, Goydos J, Ray A, and Perera RJ (2010) The regulation of miRNA-211 expression and its role in melanoma cell invasiveness. PLoS One 5:e13779.

Mazar J, Khaitan D, DeBlasio D, Zhong C, Govindarajan SS, Kopanathi S, Zhang S, Ray A, and Perera RJ (2011b) Epigenetic regulation of microRNA genes and the role of miR-34b in cell invasion and motility in human melanoma. PLoS One 6: e24922

Melnik BC (2015) MiR-21: an environmental driver of malignant melanoma? $J$ Transl Med 13:202.

Melo SA and Esteller M (2011) Dysregulation of microRNAs in cancer: playing with fire. FEBS Lett 585:2087-2099.

Mendell JT and Olson EN (2012) MicroRNAs in stress signaling and human disease. Cell 148:1172-1187.

Migliore C, Petrelli A, Ghiso E, Corso S, Capparuccia L, Eramo A, Comoglio PM, and Giordano S (2008) MicroRNAs impair MET-mediated invasive growth. Cancer Res 68:10128-10136.

Min D, Lv XB, Wang X, Zhang B, Meng W, Yu F, and Hu H (2013) Downregulation of miR-302c and miR-520c by $1,25(\mathrm{OH}) 2 \mathrm{D} 3$ treatment enhances the susceptibility of tumour cells to natural killer cell-mediated cytotoxicity. $\mathrm{Br} J$ Cancer 109:723-730

Mishra PJ, Mishra PJ, and Merlino G (2016) Integrated genomics identifies miR32/MCL-1 pathway as a critical driver of melanomagenesis: implications for miRreplacement and combination therapy. PLoS One 11:e0165102.

Mueller DW and Bosserhoff AK (2011) MicroRNA miR-196a controls melanomaassociated genes by regulating HOX-C8 expression. Int J Cancer 129:1064-1074. 
Mueller DW, Rehli M, and Bosserhoff AK (2009) miRNA expression profiling in melanocytes and melanoma cell lines reveals miRNAs associated with formation and progression of malignant melanoma. J Invest Dermatol 129:1740-1751.

Müller DW and Bosserhoff AK (2008) Integrin $\beta_{3}$ expression is regulated by let-7a miRNA in malignant melanoma. Oncogene 27:6698-6706.

Muramatsu T and Miyauchi T (2003) Basigin (CD147): a multifunctional transmembrane protein involved in reproduction, neural function, inflammation and tumor invasion. Histol Histopathol 18:981-987.

Nelson KM and Weiss GJ (2008) MicroRNAs and cancer: past, present, and potential future. Mol Cancer Ther 7:3655-3660.

Nelson MA, Reynolds SH, Rao UN, Goulet AC, Feng Y, Beas A, Honchak B, Averill J, Lowry DT, Senft JR, et al. (2006) Increased gene copy number of the transcription factor E2F1 in malignant melanoma. Cancer Biol Ther 5:407-412.

Noguchi S, Kumazaki M, Mori T, Baba K, Okuda M, Mizuno T, and Akao Y (2016) Analysis of microRNA-203 function in CREB/MITF/RAB27a pathway: comparison between canine and human melanoma cells. Vet Comp Oncol 14:384-394.

Noguchi S, Mori T, Hoshino Y, Yamada N, Nakagawa T, Sasaki N, Akao Y, and Maruo K (2012) Comparative study of anti-oncogenic microRNA-145 in canine and human malignant melanoma. $J$ Vet Med Sci 74:1-8.

Noguchi S, Mori T, Nakagawa T, Itamoto K, Haraguchi T, and Mizuno T (2015) DNA methylation contributes toward silencing of antioncogenic microRNA-203 in human and canine melanoma cells. Melanoma Res 25:390-398.

O'Connell RM, Rao DS, and Baltimore D (2012) microRNA regulation of inflammatory responses. Annu Rev Immunol 30:295-312.

Pencheva N, Tran H, Buss C, Huh D, Drobnjak M, Busam K, and Tavazoie SF (2012) Convergent multi-miRNA targeting of ApoE drives LRP1/LRP8-dependent melanoma metastasis and angiogenesis. Cell 151:1068-1082.

Persson H, Kvist A, Rego N, Staaf J, Vallon-Christersson J, Luts L, Loman N, Jonsson G, Naya H, Hoglund M, et al. (2011) Identification of new microRNAs in paired normal and tumor breast tissue suggests a dual role for the ERBB2/Her2 gene. Cancer Res 71:78-86.

Pillai RS, Artus CG, and Filipowicz W (2004) Tethering of human Ago proteins to mRNA mimics the miRNA-mediated repression of protein synthesis. RNA 10: $1518-1525$.

Pinto R, Strippoli S, De Summa S, Albano A, Azzariti A, Guida G, Popescu O, Lorusso V, Guida M, and Tommasi S (2015) MicroRNA expression in BRAF-mutated and wild-type metastatic melanoma and its correlation with response duration to BRAF inhibitors. Expert Opin Ther Targets 19:1027-1035.

Poell JB, van Haastert RJ, de Gunst T, Schultz IJ, Gommans WM, Verheul M, Cerisoli F, van Noort PI, Prevost GP, Schaapveld RQ, et al. (2012) A functional screen identifies specific microRNAs capable of inhibiting human melanoma cell viability. PLoS One 7:e43569.

Poliseno L, Haimovic A, Segura MF, Hanniford D, Christos PJ, Darvishian F, Wang J, Shapiro RL, Pavlick AC, Berman RS, et al. (2012) Histology-specific microRNA alterations in melanoma. J Invest Dermatol 132:1860-1868.

Prasad R and Katiyar SK (2014) Down-regulation of miRNA-106b inhibits growth of melanoma cells by promoting G1-phase cell cycle arrest and reactivation of p21/WAF1/Cip1 protein. Oncotarget 5:10636-10649.

Reuland SN, Smith SM, Bemis LT, Goldstein NB, Almeida AR, Partyka KA, Marquez VE, Zhang Q, Norris DA, and Shellman YG (2013) MicroRNA-26a is strongly downregulated in melanoma and induces cell death through repression of silencer of death domains (SODD). J Invest Dermatol 133:1286-1293.

Richtig G, Ehall B, Richtig E, Aigelsreiter A, Gutschner T, and Pichler M (2017) Function and clinical implications of long non-coding RNAs in melanoma. Int $\mathrm{J} \mathrm{Mol}$ Sci 18:E715.

Rigel DS (2008) Cutaneous ultraviolet exposure and its relationship to the development of skin cancer. J Am Acad Dermatol 58(Suppl 2):S129-S132.

Sahu RP (2015) Expression of the platelet-activating factor receptor enhances benzyl isothiocyanate-induced apoptosis in murine and human melanoma cells. Mol Med Rep 12:394-400.

Sahu RP, Ferracini M, and Travers JB (2015) Systemic chemotherapy is modulated by platelet-activating factor-receptor agonists. Mediators Inflamm 2015:820543.

Sahu RP, Harrison KA, Weyerbacher J, Murphy RC, Konger RL, Garrett JE, ChinSinex HJ, Johnston ME, II, Dynlacht JR, Mendonca M, et al. (2016) Radiation therapy generates platelet-activating factor agonists. Oncotarget 7:20788-20800.

Sahu RP, Konger RL, and Travers JB (2014a) Platelet-activating factor-receptor and tumor immunity. JSM Cell Dev Biol 2:1008.

Sahu RP, Ocana JA, Harrison KA, Ferracini M, Touloukian CE, Al-Hassani M, Sun L, Loesch M, Murphy RC, Althouse SK, et al. (2014b) Chemotherapeutic agents subvert tumor immunity by generating agonists of platelet-activating factor. Cancer Res 74:7069-7078.

Sahu RP, Turner MJ, DaSilva SC, Rashid BM, Ocana JA, Perkins SM, Konger RL, Touloukian CE, Kaplan MH, and Travers JB (2012) The environmental stressor ultraviolet $\mathrm{B}$ radiation inhibits murine antitumor immunity through its ability to generate platelet-activating factor agonists. Carcinogenesis 33:1360-1367.

Saldanha G, Elshaw S, Sachs P, Alharbi H, Shah P, Jothi A, and Pringle JH (2016a) microRNA-10b is a prognostic biomarker for melanoma. Mod Pathol 29 $112-121$

Saldanha G, Potter L, Lee YS, Watson S, Shendge P, and Pringle JH (2016b) MicroRNA-21 expression and its pathogenetic significance in cutaneous melanoma. Melanoma Res 26:21-28.

Salta E and De Strooper B (2012) Non-coding RNAs with essential roles in neurodegenerative disorders. Lancet Neurol 11:189-200.

Samir M and Pessler F (2016) Small non-coding RNAs associated with viral infectious diseases of veterinary importance: potential clinical applications. Front Vet Sci 3:22.

Satzger I, Mattern A, Kuettler U, Weinspach D, Niebuhr M, Kapp A, and Gutzmer R 2012) microRNA-21 is upregulated in malignant melanoma and influences apoptosis of melanocytic cells. Exp Dermatol 21:509-514.
Satzger I, Mattern A, Kuettler U, Weinspach D, Voelker B, Kapp A, and Gutzmer R (2010) MicroRNA-15b represents an independent prognostic parameter and is correlated with tumor cell proliferation and apoptosis in malignant melanoma. Int $J$ Cancer 126:2553-2562.

Scaria V, Hariharan M, Maiti S, Pillai B, and Brahmachari SK (2006) Host-virus interaction: a new role for microRNAs. Retrovirology 3:68.

Schultz J, Lorenz P, Gross G, Ibrahim S, and Kunz M (2008) MicroRNA let-7b targets important cell cycle molecules in malignant melanoma cells and interferes with anchorage-independent growth. Cell Res 18:549-557.

Seftor RE, Seftor EA, Gehlsen KR, Stetler-Stevenson WG, Brown PD, Ruoslahti E, and Hendrix MJ (1992) Role of the alpha $\alpha_{\mathrm{v}} \beta_{3}$ integrin in human melanoma cell invasion. Proc Natl Acad Sci USA 89:1557-1561.

Segura MF, Hanniford D, Menendez S, Reavie L, Zou X, Alvarez-Diaz S, Zakrzewski J, Blochin E, Rose A, Bogunovic D, et al. (2009) Aberrant miR-182 expression promotes melanoma metastasis by repressing FOXO3 and microphthalmiaassociated transcription factor. Proc Natl Acad Sci USA 106:1814-1819.

Segura MF, Greenwald HS, Hanniford D, Osman I, and Hernando E (2012) MicroRNA and cutaneous melanoma: from discovery to prognosis and therapy. Carcinogenesis 33:1823-1832.

Shao NY, Hu HY, Yan Z, Xu Y, Hu H, Menzel C, Li N, Chen W, and Khaitovich P (2010) Comprehensive survey of human brain microRNA by deep sequencing. BMC Genomics 11:409.

Shi S, Han L, Deng L, Zhang Y, Shen H, Gong T, Zhang Z, and Sun X (2014) Dual drugs (microRNA-34a and paclitaxel)-loaded functional solid lipid nanoparticles for ynergistic cancer cell suppression. J Control Release 194:228-237.

Sosman JA, Kim KB, Schuchter L, Gonzalez R, Pavlick AC, Weber JS, McArthur GA, Hutson TE, Moschos SJ, Flaherty KT, et al. (2012) Survival in BRAF V600-mutant advanced melanoma treated with vemurafenib. $N$ Engl $J$ Med 366:707-714.

Stark MS, Bonazzi VF, Boyle GM, Palmer JM, Symmons J, Lanagan CM, Schmidt CW, Herington AC, Ballotti R, Pollock PM, et al. (2015) miR-514a regulates the tumour suppressor NF1 and modulates BRAFi sensitivity in melanoma. Oncotarget 6:17753-17763.

Streicher KL, Zhu W, Lehmann KP, Georgantas RW, Morehouse CA, Brohawn P, Carrasco RA, Xiao Z, Tice DA, Higgs BW, et al. (2012) A novel oncogenic role for the miRNA-506-514 cluster in initiating melanocyte transformation and promoting melanoma growth. Oncogene 31:1558-1570.

Sun V, Zhou WB, Majid S, Kashani-Sabet M, and Dar AA (2014) MicroRNA-mediated regulation of melanoma. Br J Dermatol 171:234-241.

Sun X, Li J, Sun Y, Zhang Y, Dong L, Shen C, Yang L, Yang M, Li Y, Shen G, et al. (2016) miR-7 reverses the resistance to BRAFi in melanoma by targeting EGFR/IGF-1R/CRAF and inhibiting the MAPK and PI3K/AKT signaling pathways. Oncotarget 7:53558-53570.

Suryadinata R, Sadowski M, and Sarcevic B (2010) Control of cell cycle progression by phosphorylation of cyclin-dependent kinase (CDK) substrates. Biosci Rep 30: $243-255$

Terando A, Sabel MS, and Sondak VK (2003) Melanoma: adjuvant therapy and other treatment options. Curr Treat Options Oncol 4:187-199.

Tian Y, Wei W, Li L, and Yang R (2015) Down-regulation of miR-148a promotes metastasis by DNA methylation and is associated with prognosis of skin cancer by targeting TGIF2. Med Sci Monit 21:3798-3805.

Tüfekci KU, Meuwissen RL, and Genc S (2014) The role of microRNAs in biological processes. Methods Mol Biol 1107:15-31.

Umemura S, Shirane M, Takekoshi S, Kusakabe T, Itoh J, Egashira N, Tokuda Y, Mori K, and Osamura YR (2009) Overexpression of E2F-5 correlates with a pathological basal phenotype and a worse clinical outcome. Br J Cancer 100:764-771.

van Rooij E, Sutherland LB, Qi X, Richardson JA, Hill J, and Olson EN (2007) Control of stress-dependent cardiac growth and gene expression by a microRNA. Science 316:575-579.

Varamo C, Occelli M, Vivenza D, Merlano M, and Lo Nigro C (2017) MicroRNAs role as potential biomarkers and key regulators in melanoma. Genes Chromosomes Cancer 56:3-10

Vasudevan S, Tong Y, and Steitz JA (2007) Switching from repression to activation: microRNAs can up-regulate translation. Science 318:1931-1934.

Vergani E, Di Guardo L, Dugo M, Rigoletto S, Tragni G, Ruggeri R, Perrone F, Tamborini E, Gloghini A, Arienti F, et al. (2016) Overcoming melanoma resistance to vemurafenib by targeting CCL2-induced miR-34a, miR-100 and miR-125b. Oncotarget 7:4428-4441.

Villanueva J and Herlyn M (2008) Melanoma and the tumor microenvironment. Curr Oncol Rep 10:439-446.

Villaruz LC, Huang G, Romkes M, Kirkwood JM, Buch SC, Nukui T, Flaherty KT, Lee SJ, Wilson MA, Nathanson KL, et al. (2015) MicroRNA expression profiling predicts clinical outcome of carboplatin/paclitaxel-based therapy in metastatic melanoma treated on the ECOG-ACRIN trial E2603. Clin Epigenetics 7:58.

Wagenseller AG, Shada A, D'Auria KM, Murphy C, Sun D, Molhoek KR, Papin JA, Dutta A, and Slingluff CL, Jr (2013) MicroRNAs induced in melanoma treated with combination targeted therapy of Temsirolimus and Bevacizumab. J Transl Med 11:218

Wagle N, Emery C, Berger MF, Davis MJ, Sawyer A, Pochanard P, Kehoe SM, Johannessen CM, Macconaill LE, Hahn WC, et al. (2011) Dissecting therapeutic resistance to RAF inhibition in melanoma by tumor genomic profiling. J Clin Oncol 29:3085-3096.

Walter KA, Hossain MA, Luddy C, Goel N, Reznik TE, and Laterra J (2002) Scatter factor/hepatocyte growth factor stimulation of glioblastoma cell cycle progression through $\mathrm{G}_{1}$ is c-Myc dependent and independent of p27 suppression, Cdk2 activation, or E2F1-dependent transcription. Mol Cell Biol 22:2703-2715.

Weber CE, Luo C, Hotz-Wagenblatt A, Gardyan A, Kordaß T, Holland-Letz T, Osen W, and Eichmüller SB (2016) miR-339-3p is a tumor suppressor in melanoma Cancer Res 76:3562-3571.

Westphal D, Glitza Oliva IC, and Niessner H (2017) Molecular insights into melanoma brain metastases. Cancer 123:2163-2175. 
White NM, Fatoohi E, Metias M, Jung K, Stephan C, and Yousef GM (2011) Metastamirs: a stepping stone towards improved cancer management. Nat Rev Clin Oncol 8:75-84.

Wightman B, Ha I, and Ruvkun G (1993) Posttranscriptional regulation of the heterochronic gene lin-14 by lin-4 mediates temporal pattern formation in C. elegans. Cell 75:855-862.

Xu Y, Brenn T, Brown ER, Doherty V, and Melton DW (2012) Differential expression of microRNAs during melanoma progression: miR-200c, miR-205 and miR-211 are downregulated in melanoma and act as tumour suppressors. $\mathrm{Br} J$ Cancer 106 $553-561$.

Yang CH, Yue J, Pfeffer SR, Handorf CR, and Pfeffer LM (2011) MicroRNA miR-21 regulates the metastatic behavior of $\mathrm{B} 16$ melanoma cells. $J$ Biol Chem 286: 39172-39178.

Zhang D, Han Y, and Xu L (2016) Upregulation of miR-124 by physcion 8-O- $\beta$-glucopyranoside inhibits proliferation and invasion of malignant melanoma cells via repressing RLIP76. Biomed Pharmacother 84:166-176.
Zhang L, Huang J, Yang N, Greshock J, Megraw MS, Giannakakis A, Liang S, Naylor TL, Barchetti A, Ward MR, et al. (2006) microRNAs exhibit high frequency genomic alterations in human cancer. Proc Natl Acad Sci USA 103:9136-9141.

Zhao Y, Wang W, Min I, Wyrwas B, Moore M, Zarnegar R, and Fahey TJ, III (2017) BRAF V600E-dependent role of autophagy in uveal melanoma. J Cancer Res Clin Oncol 143:447-455.

Zhou M, Liu Z, Zhao Y, Ding Y, Liu H, Xi Y, Xiong W, Li G, Lu J, Fodstad O, et al. (2010) MicroRNA-125b confers the resistance of breast cancer cells to paclitaxel through suppression of pro-apoptotic Bcl-2 antagonist killer 1 (Bak1) expression. $J$ Biol Chem 285:21496-21507.

Address correspondence to: Dr. Ravi Prakash Sahu, Department of Pharmacology and Toxicology, 230 Health Sciences Building, Wright State University, 3640 Colonel Glenn Hwy, Dayton, OH 45435. E-mail: ravi.sahu@wright.edu 